Arch. Tierz., Dummerstorf 45 (2002) 3, 297-305

Department of Animal Science, Obafemi Awolowo University, Ile-Ife, Nigeria

SUNDAY A. ADEDOKUN and EMMANUEL B. SONAIYA

\title{
Crossbreeding Nigeria Indigenous with the Dahlem Red chickens for improved productivity and adaptability
}

\begin{abstract}
Summary
In a 5-year crossbreeding experiment, specific groups of the Nigeria Indigenous chicken (NI) from two ecological zones (i.e. Fulani, Fu; Fulani dwarf, FuD from the Northern Guinea Savanna and Yoruba, Y, from the Derived Savanna) and the German Dahlem Red normal (DR) and Dahlem Red Dwarf (DRD) were used to produce four genetic groups DR x Fu, Fu x DR, DR x Y, and FuD x DRD which were evaluated for age and weight at first egg, egg weight, percent hen-day egg production, percent laying mortality and resistance to disease. A total of $505 \mathrm{NI}$ growers and 584 and 48 imported day-old DR and DRD chicks, respectively, were evaluated as parent stock. Data compilation was by DBase IV. Data were analysed using the General Linear Model (GLM) procedure of Statistical Analysis System (SAS, 1986).

For all the traits evaluated, there was no significant difference $(\mathrm{P}>0.05)$ between NI from the three ecological zones. Therefore, pooled NI means were compared with the means for the DR and the crosses between them. Mean 280-day egg weights were 55.7, 36.8 and 42.9g, respectively, for DR, NI and the crosses while DR, NI and crosses produced 103, 70 and 83 eggs, respectively, over a period of 196 days. The DR x Fu cross had a significantly higher $(\mathrm{P} \leq 0.05)$ egg weight for most of the periods studied with mean egg weight of 46.1g. The 280-day egg production of DR x Fu, (148) was significantly higher $(\mathrm{P}<0.05)$ than that of DR x Y and Fu x DR (119) and FuD x DRD (87). At week 40, $\mathrm{DR} x \mathrm{Fu}$ females were significantly heavier $(\mathrm{p}<0.05)$ than all the females of the other groups while the FuD $\mathrm{x}$ DRD progeny had the least body weights at all the ages studied. Overall, DR x Fu and DR x Y were superior to Fu x DR and FuD x DRD for most of the traits studied. Results of the skin test using Skin response to Phytohaemagglutinin inoculation showed FuD x DRD, DR x Y and Fu x DR with values of $0.45 \mathrm{~mm}, 0.36 \mathrm{~mm}$ and $0.34 \mathrm{~mm}$, respectively. Inbred lines DR x DR and Y x Y gave values of 0.33 and 0.50 , respectively.
\end{abstract}

Key Words: Nigeria Indigenous chicken, Dahlem Red, crossbreeding, derived savanna, guinea savanna, rain forest, age and weight at first egg, egg weight, percent laying mortality

\section{Zusammenfassung}

Titel der Arbeit: Kreuzungen einheimischer Nigerianischer Hühnerrassen mit Red Dahlem zur Verbesserung der Legeleistung und Anpassungsfähigkeit

Aus drei ökologischen Zonen innerhalb Nigerias stammende einheimische Hühnerrassen nämlich Fulani (Fu), Fulani Dwarf (FuD) und Yoruba (Y), die als repräsentativ für das Land gelten können, wurden mit German Dahlem Red (DR) und Dahlem Red Dwarf (DRD) in mehreren unterschiedlichen Kombinationen gekreuzt. In einem 5-jährigen Experiment konnten sie hinsichtlich Leistung und Anpassungsfähigkeit verglichen werden. Erfasst wurden die Merkmale: Körpergewicht von der 8. bis 72. Lebenswoche, Alter und Gewicht bei Beginn der Legeperiode, Legeleistung, Eigewichte und Krankheitsresistenz. 505 einheimische und aus Deutschland importierte 584 DR sowie 48 DRD Eintagsküken wurden als Elternpopulationen eingesetzt. Bei allen untersuchten Merkmalen bestanden zwischen den einheimischen Populationen keine signifikanten Unterschiede, so dass diese zusammengefasst werden konnten (NI). Beim Vergleich der drei Gruppen nämlich DR, NI und Kreuzungen ergaben sich am 280. Tag keine Unterschiede bezüglich des Legebeginns jedoch signifikante Unterschiede in den Eigewichten (55,7; 36,8; und 42,9 g) und der Legeleistung (103, 70 und 83 Eier) in der Legeperiode von 196 Tagen. Unter den Kreuzungsgruppen erreichten die DR x Fu Kreuzungen mit 46,1 g die signifikant höchsten Eigewichte. Die Eiproduktion bis zum 280. Tag lag bei den Fu Tieren mit 148 Eiern signifikant höher als bei DR x Y und Fu x DR mit 119 und der FuD x DRD Tiere mit 87 Eiern. Im Alter von 40 Wochen waren die DR x Fu Hennen signifikant schwerer als die Hennen aller anderen Kreuzungsgruppen, während die FuD x DRD Tiere während der gesamten Kontrollzeit die geringsten Gewichte aufwiesen. Im allgemeinen erreichten die DR x Fu und die DR x Y bei fast allen untersuchten Merkmalen bessere Werte als die Fu x DR bzw. FuD x DRD. Die Ergebnisse des Hauttestes nach Phytohaemagglutinin-Injektion als Indikator für 
Krankheitsresistenz ergaben für die einheimischen Populationen den besten, für DR x DR den ungünstigsten Wert.

Schlüsselwörter: Nigerianische einheimische Hühner, Dahlem Red, Rassenkreuzung, Alter und Gewicht bei Legebeginn, Legeleistung, Eigewicht

\section{Introduction}

Different breeds of exotic chickens have been used in crossbreeding experiments with NI chicken. Most of these breeds were the egg laying types. Breeds that have been used include Gold-Link (NWOSU and OMEJE, 1985) and Apollo (AKINOKUN and DETTMERS, 1977). In this experiment, Dahlem Red, a dual purpose breed, was used with the intention of improving not only the laying performance of the NIC hens but also to improve their salvage value at the end of the laying period. Also, special attention was placed on the type of local chickens used in the experiment. Fulani chickens which have been reported to be heavier than the other Nigerian indigenous chickens (ATTEH, 1990; OLORI, 1992) and its dwarf cocks were used in this experiment. Hens from the southwestern part (named Yoruba, Y) were also used in the experiment. While comparing the Ife collection of the NI chicken with the Apollo breed, AKINOKUN and DETTMERS (1977) reported that there was significant breed effect on egg production to eight months of lay. The weight of Apollo eggs was significantly higher than those of Ife hens, with a difference of $14 \mathrm{~g}$ at first egg and $16 \mathrm{~g}$ at five months in production. NWOSU (1990) reported that a comparison of cross-bred groups after the 12th week of age when maternal influences no longer affected body weight showed that crossing the exotic cocks with local hens improved the growth of the local chicken while OMEJE and NWOSU (1984) showed that local cocks transmit genes for early age at first egg when crossed with exotic hens.

\section{Materials and Methods}

A total of 505 growers were purchased from six locations from three ecological zones within Nigeria. These locations were Nsukka in the south east and Sagamu in the south west (Rain Forest, RF, 170); Ilorin in the western north central and Makurdi in the eastern north central (Derived Savanna, DS, 165); and Kaduna in the northern west and Jos in the northern east (Guinea Savanna, GS, 170). These collections represented the foundation stock of the NI. A total of 584 Dahlem Red normal (DR) and 48 Dahlem Red Dwarf (DRD) were imported from Germany at day old. All the birds, local and exotic, were fed ad libitum on commercial rations and raised on deep litter until 16 weeks of age.

These $F_{0}$ hens were transferred into cages and monitored for body weight, age and body weight at first egg, daily egg production and egg weight. Each period was made up of 28 days. There was no significant difference $(P>0.05)$ between hens from the three ecological zones as it relates to age at first egg, mean egg production, and mean egg weight, for the duration of the experiment. Therefore, pooled means were compared with the means for the DR, NI and the crosses between them.

For the birds used in crossing, the only criterion used in selection was the health status of the birds. Deformed, runted, dull and sick birds were excluded from the mating programme. A total of 79 females and 16 males were used in the crossbreeding experiment with a mating ratio used was one cock to five females. Four different crossings were carried out for the production of $F_{1}$ : Dahlem Red x Yoruba (DR x Y), 
Fulani x Dahlem Red (Fu x DR), Dahlem Red x Fulani (DR x Fu), and Fulani Dwarf x Dahlem Red Dwarf (FuD x DRD). Body weights were taken at 8, 15, 20, 40 and 72 weeks using a top loading Waymaster spring balance.

A total of 362 eggs from the cross matings were collected and incubated in a forced draught incubator (Fan Hatch, manufactured by Reliable Thermostat Co. Ltd., Branley Rotherham, South Yorkshire, England).

Data collected were subjected to analysis of variance (SAS, 1986) for unequal subclass numbers using the statistical model: $\quad \mathbf{Y}_{\mathbf{i j k}}=\mathbf{U}+\mathbf{G}_{\mathbf{i}}+\mathbf{S}_{\mathbf{j}}+(\mathbf{G S})_{\mathbf{i j}}+\mathbf{E}_{\mathbf{i j k}}$

where: $\quad Y_{i j k} \quad=$ observed value of a dependent variable; $U=$ overall mean.

$\mathrm{G}_{\mathrm{i}} \quad=$ Effect of the ith group $(1,2,3)$

$\mathrm{S}_{\mathrm{I}} \quad=$ Effect of the $\mathrm{jth} \operatorname{sex}(\mathrm{j}=\mathrm{m}, \mathrm{f})$

$(\mathrm{GS})_{\mathrm{ij}}=$ Effect of the interaction between ecotype group and sex

\section{Results and Discussion}

Table 1 shows the least-squares means and standard errors of body weight of the DR, $\mathrm{NI}$ and the crosses between them. Mean body weights of DR x Fu and Fu x DR hens of $1537 \pm 72.5 \mathrm{~g}$ and $1320+41.9 \mathrm{~g}$ at 40 weeks, respectively, were lower than $1620 \mathrm{~g}$ reported for mature Fulani hens but higher than $1290 \mathrm{~g}$ reported for the non-Fulani NI hens (ATTEH, 1990). Likewise, a weight of $1306 \pm 41.9 \mathrm{~g}$ observed in DR x Y at 40 weeks is higher than $1290 \mathrm{~g}$ reported by ATTEH (1990) for mature NI hens outside the Fulani kraals. AKINOKUN (1990) reported $908.7 \pm 26.6 \mathrm{~g}$ for the mean body weight of NI hens at 20 weeks of age. This weight is much lower than the mean body weight recorded for the crosses at 20 weeks in this experiment. This may be due to the effect of the exotic DR (dual purpose) used in this study. The mean body weight for hybrid hens, except for FuD x DRD, was slightly lower than the mean body weight of $1700 \mathrm{~g}$ at the end of lay for the 6 exotic breeds and crosses reported by AKINOKUN (1974). The NI males and females mean body weights were significantly lower than their respective crosses and the DR at week 8 while their weights were not significantly different at 15 weeks. At 20 and 40 weeks, NI mean body weight was significantly $(\mathrm{p}<0.05)$ lower that that of the crosses except the cross between DRD and Y. This could be attributed to the effect of the dwarf cock.

Table 1

Least-squares means (g) and standard errors of body weight of Dahlem Red, Nigeria Indigenous chicken and the crosses between them

\begin{tabular}{|c|c|c|c|c|c|c|}
\hline Crosses & Sex & $\begin{array}{l}\text { Wk8 } \\
\text { Mean } \pm \text { S.E }\end{array}$ & $\begin{array}{l}\text { Wk15 } \\
\text { Mean } \pm \text { S.E }\end{array}$ & $\begin{array}{l}\text { Wk20 } \\
\text { Mean } \pm \text { S.E }\end{array}$ & $\begin{array}{l}\text { Wk40 } \\
\text { Mean } \pm \text { S.E }\end{array}$ & $\begin{array}{l}\text { Wk72 } \\
\text { Mean } \pm \text { S.E }\end{array}$ \\
\hline $\mathrm{DR} \times \mathrm{Fu}$ & $\bar{F}$ & $468 \pm 33.1^{\mathrm{ab}}$ & $860 \pm 56.7^{\mathrm{a}}$ & $1275 \pm 79.6^{\mathrm{bc}}$ & $1537 \pm 72.5^{c}$ & $\overline{\text { n.a }}$ \\
\hline $\mathrm{DR} \times \mathrm{Fu}$ & M & $508 \pm 25.0^{\mathrm{a}}$ & $871 \pm 42.8^{a}$ & $1360 \pm 60.2^{\mathrm{b}}$ & n.a & n.a \\
\hline $\mathrm{Fu} \times \mathrm{DR}$ & $\mathrm{F}$ & $372 \pm 18.3^{b}$ & $866 \pm 31.4^{\mathrm{a}}$ & $1216 \pm 44.2^{\mathrm{bc}}$ & $1320 \pm 41.9^{\mathrm{d}}$ & n.a \\
\hline $\mathrm{Fu} \times \mathrm{DR}$ & M & $390 \pm 38.2^{b}$ & $933 \pm 65.4^{\mathrm{a}}$ & $1333 \pm 91.9^{b}$ & n.a & n.a \\
\hline DR $x Y$ & $\mathrm{~F}$ & $389 \pm 19.1^{\mathrm{b}}$ & $698 \pm 32.7^{\mathrm{b}}$ & $1143 \pm 46.0^{\mathrm{cd}}$ & $1306 \pm 41.9^{\mathrm{d}}$ & n.a \\
\hline DR $x Y$ & M & $429 \pm 25.0^{\mathrm{ab}}$ & $781 \pm 42.8^{\mathrm{ab}}$ & $1336 \pm 60.2^{\mathrm{b}}$ & n.a & n.a \\
\hline FuD $x$ DR & $\mathrm{DF}$ & $308 \pm 29.6^{c}$ & $486 \pm 50.7^{c}$ & $714 \pm 71.2^{\mathrm{f}}$ & $784 \pm 64.9^{f}$ & n.a \\
\hline FuD x DR & $\mathrm{D} M$ & $304 \pm 27.0^{c}$ & $560 \pm 46.3^{c}$ & $1023 \pm 65.0^{\mathrm{d}}$ & n.a & n.a \\
\hline NIC & $\mathrm{F}$ & $252 \pm 29.5^{\mathrm{d}}$ & $721 \pm 72.8^{\mathrm{b}}$ & $970 \pm 32.3^{\mathrm{e}}$ & $997 \pm 32.2^{\mathrm{e}}$ & $1144 \pm 133.3^{\mathrm{d}}$ \\
\hline NIC & M & $283 \pm 23.1^{\mathrm{d}}$ & $862 \pm 56.5^{\mathrm{a}}$ & $1191 \pm 40.5^{\mathrm{cd}}$ & $1341 \pm 40.4^{\mathrm{d}}$ & $1449 \pm 101.9^{c}$ \\
\hline DR & $\mathrm{F}$ & $412 \pm 18.9^{\mathrm{ab}}$ & n.a & $1331 \pm 244.2^{b}$ & $1986 \pm 173.6^{b}$ & $2033 \pm 134.7^{b}$ \\
\hline DR & M & $466 \pm 24.2^{\mathrm{ab}}$ & n.a & $1731 \pm 300.5^{a}$ & $2913 \pm 379.9^{a}$ & $2966 \pm 131.4^{\mathrm{a}}$ \\
\hline
\end{tabular}

${ }_{\text {abcdef }}=$ means within column with different superscripts are significantly different $(\mathrm{p}<0.05)$; Fu = Fulani; DR = Dahlem Red; NI = Nigeria Indigenous chicken; DRD = Dahlem Red Dwarf; $\mathrm{Y}=$ Yoruba; FuD = Fulani Dwarf; n.a = not available. 
The daily rate of gain of the crosses between the Dahlem Red and the Nigerian indigenous chicken is as shown in Figure 1. Daily rate of gain in both sexes increased from $3.8 \mathrm{~g} /$ day in the 8 th week to $16 \mathrm{~g}$ /day in the 20 th week. The least rate of gain was recorded for the female progeny of FuD cock and DRD hen. The rate of gain for the cocks was higher than that of the females except for the DR x Fu cross in which the hens' mean daily gain was $0.6 \mathrm{~g}$ higher than that of the cock whose mean daily gain was $7.4 \mathrm{~g}$ between 8 and 15 weeks. The highest daily gain of 13.2g was recorded for the Fu x DRD cock between 15 and 20 weeks.

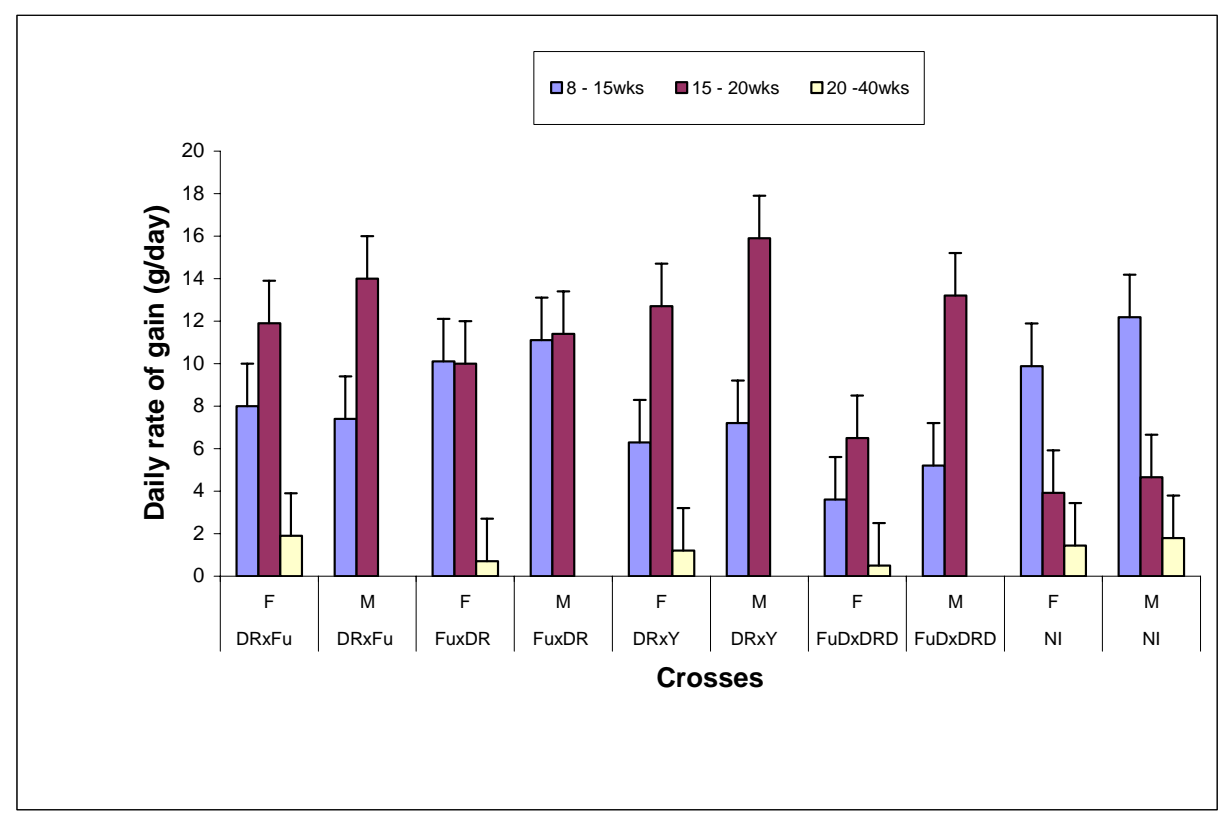

Fig. 1: Daily rate of gain (g/d) of Nigeria Indigenous chicken and their crosses with Dahlem Red

Egg production by the crosses over a 280-day period is as shown in Table 2. The DR $\mathrm{x}$ Fu cross gave the highest number of 148 eggs per hen while its reciprocal cross Fu $x$ DR gave a lower $(\mathrm{P}<0.05)$ number of 119 eggs per hen. This suggests that the exotic cock

Table 2

Least-squares means and standard error of egg production (egg number), age (days) and weight (g) at first egg of the crosses between the Nigeria Indigenous chicken and Dahlem Red

\begin{tabular}{lllll}
\hline Month-in-lay & $\begin{array}{l}\text { Fu x DR } \\
\text { Mean } \pm \text { S.E }\end{array}$ & $\begin{array}{l}\text { DR x Fu } \\
\text { Mean } \pm \text { S.E }\end{array}$ & $\begin{array}{l}\text { DR x Y } \\
\text { Mean } \pm \text { S.E }\end{array}$ & $\begin{array}{l}\text { FuD x DRD } \\
\text { Mean } \pm \text { S.E }\end{array}$ \\
\hline 1 & $9.2 \pm 0.9^{\mathrm{a}}$ & $4.8 \pm 1.7^{\mathrm{b}}$ & $5.1 \pm 1.0^{\mathrm{b}}$ & $4.3 \pm 1.7^{\mathrm{b}}$ \\
2 & $17.1 \pm 1.0^{\mathrm{a}}$ & $20.3 \pm 1.8^{\mathrm{a}}$ & $17.6 \pm 1.0^{\mathrm{a}}$ & $10.8 \pm 1.6^{\mathrm{b}}$ \\
3 & $13.2 \pm 1.1^{\mathrm{b}}$ & $20.0 \pm 2.0^{\mathrm{a}}$ & $11.8 \pm 1.1^{\mathrm{bc}}$ & $8.4 \pm 1.8^{\mathrm{c}}$ \\
4 & $11.4 \pm 1.1^{\mathrm{ab}}$ & $14.8 \pm 2.0^{\mathrm{a}}$ & $10.9 \pm 1.2^{\mathrm{ab}}$ & $9.6 \pm 1.8^{\mathrm{b}}$ \\
5 & $12.9 \pm 0.8^{\mathrm{b}}$ & $16.3 \pm 1.4^{\mathrm{a}}$ & $12.8 \pm 0.8^{\mathrm{b}}$ & $9.4 \pm 1.3^{\mathrm{c}}$ \\
6 & $12.2 \pm 1.2^{\mathrm{a}}$ & $11.5 \pm 2.2^{\mathrm{a}}$ & $12.5 \pm 1.3^{\mathrm{a}}$ & $10.2 \pm 1.9^{\mathrm{a}}$ \\
7 & $12.6 \pm 1.1^{\mathrm{a}}$ & $15.3 \pm 1.9^{\mathrm{a}}$ & $11.4 \pm 1.1^{\mathrm{ab}}$ & $8.0 \pm 1.7^{\mathrm{b}}$ \\
8 & $10.5 \pm 1.0^{\mathrm{a}}$ & $14.5 \pm 1.8^{\mathrm{a}}$ & $13.3 \pm 1.0^{\mathrm{a}}$ & $12.8 \pm 1.6^{\mathrm{a}}$ \\
9 & $10.0 \pm 1.0^{\mathrm{a}}$ & $12.3 \pm 1.8^{\mathrm{a}}$ & $12.3 \pm 1.0^{\mathrm{a}}$ & $13.4 \pm 1.6^{\mathrm{a}}$ \\
10 & $10.2 \pm 0.7^{\mathrm{b}}$ & $17.8 \pm 1.2^{\mathrm{a}}$ & $11.6 \pm 1.0^{\mathrm{a}}$ & $\mathrm{n} . \mathrm{a}$ \\
$28-$ day mean egg & $11.9 \pm 1.0^{\mathrm{b}}$ & $14.8 \pm 1.8^{\mathrm{a}}$ & $11.9 \pm 1.1^{\mathrm{b}}$ & $8.7 \pm 1.5^{\mathrm{c}}$ \\
production & & & & \\
Age at first egg & $151.4 \pm 1.4^{\mathrm{b}}$ & $160.0 \pm 2.6^{\mathrm{a}}$ & $161.3 \pm 1.5^{\mathrm{a}}$ & $161.6 \pm 2.3^{\mathrm{a}}$ \\
(days) & & & & \\
Body weight at first & & & $1200.0 \pm 63.4^{\mathrm{a}}$ & $750.0 \pm 114.3^{\mathrm{b}}$ \\
egg (g) & $1229.3 \pm 1.8^{\mathrm{a}}$ & $1322.5 \pm 114.3^{\mathrm{a}}$ & &
\end{tabular}


transmits the gene for higher egg production. This agrees with the findings of NWOSU; OMEJE (1985) who reported that egg production of the main cross (GL x LC) on the average per hen was higher than for the reciprocal (LC x GL).

The Fu $x$ DR hens came into lay at a significantly earlier $(\mathrm{P}<0.05)$ age than the hens of DR x Y, DR x Fu and FuD x DRD (Table 2). This suggests that the Fulani (a local strain) cock transmits genes for early age at first egg. This agrees with the findings of OMEJE and NWOSU (1984) who reported that genetic groups sired by the local cock (LC x LC and LC x GL) had significantly $(\mathrm{P}<0.05)$ earlier age at first egg. But the result of the present study suggests that this may not be the case with the FuD cock as the age at first egg of its progeny - FuD x DRD - was significantly higher than that of Fu x DR. Body weight at first egg for all the crosses were not different except for FuD x DRD whose mean body weight was lower. However, these crosses were heavier than what OMEJE and NWOSU reported for the cross between GL x LC and LC x GL of 1186.67g and $1165.09 \mathrm{~g}$, respectively. This may be due to the fact that the exotics used in this experiment were from a dual-purpose breed, which combines egg production with good body weight.

Table 3

Least-squares means and standard errors of egg production and age at first egg of Dahlem Red, Nigeria Indigenous chicken and their crosses

\begin{tabular}{|c|c|c|c|c|c|c|c|}
\hline \multirow[t]{2}{*}{ Month-in-lay } & \multicolumn{2}{|c|}{ Dahlem Red } & \multicolumn{2}{|l|}{ NI } & \multicolumn{2}{|c|}{ Crosses } & \multirow[b]{2}{*}{$* \% \mathrm{~S}$} \\
\hline & $\mathrm{N}$ & Mean \pm S.E & $\mathrm{N}$ & Mean \pm S.E & $\mathrm{N}$ & Mean \pm S.E & \\
\hline 2 & 31 & $18 \pm 1.1^{\mathrm{a}}$ & 75 & $14 \pm 0.7^{b}$ & 36 & $16 \pm 1.0^{\mathrm{a}}$ & 14.3 \\
\hline 3 & 31 & $14 \pm 1.0^{\mathrm{a}}$ & 76 & $14 \pm 0.6^{\mathrm{a}}$ & 36 & $13 \pm 0.9^{\mathrm{a}}$ & -7.1 \\
\hline 6 & 25 & $14 \pm 0.8^{\mathrm{a}}$ & 71 & $7 \pm 0.5^{c}$ & 35 & $12 \pm 0.7^{\mathrm{b}}$ & 71.4 \\
\hline 7 & 24 & $15 \pm 0.8^{\mathrm{a}}$ & 68 & $10 \pm 0.5^{\mathrm{b}}$ & 35 & $12 \pm 0.7^{\mathrm{b}}$ & 20.0 \\
\hline 8 & 24 & $14 \pm 0.8^{a}$ & 69 & $9 \pm 0.5^{c}$ & 35 & $12 \pm 0.7^{\mathrm{b}}$ & 33.3 \\
\hline 9 & 24 & $15 \pm 0.8^{\mathrm{a}}$ & 69 & $9 \pm 0.5^{\mathrm{b}}$ & 35 & $6 \pm 0.8^{c}$ & 33.3 \\
\hline 10 & 24 & $13 \pm 0.9^{\mathrm{a}}$ & 62 & $7 \pm 0.5^{b}$ & 22 & $12 \pm 0.8^{\mathrm{a}}$ & 71.4 \\
\hline $\begin{array}{l}\text { 28-day mean egg } \\
\text { production }\end{array}$ & 26 & $15 \pm 0.8^{\mathrm{a}}$ & 70 & $10 \pm 0.5^{c}$ & 33 & $12 \pm 0.8^{b}$ & 33.8 \\
\hline AFE (days) & 22 & $160 \pm 2.6^{\mathrm{a}}$ & 75 & $159 \pm 1.7^{\mathrm{a}}$ & 33 & $157 \pm 1.7^{\mathrm{a}}$ & n.a \\
\hline
\end{tabular}

$\mathrm{abc}=$ means within row with different superscripts are significantly different $(\mathrm{p}<0.05) ; \mathrm{N}=$ number of records used in the computation; $\mathrm{NI}=$ Nigeria Indigenous chicken; AFE= Age at first egg; *\% $=$ Percent superiority of the crosses over the NI

Table 3 shows that DR had a superior egg production relative to both the NI and their crosses at most of the ages in lay while crosses were better than the NI in egg production. This result agrees with the findings of NWOSU and OMEJE (1985). They reported that the GL x LC, and imported Gold-Link (GL) were, respectively, 46\% and 55\% better than the local chicken hen in terms of annual egg production. The egg production of the crosses was superior to that of the NI throughout the period of study except at the third month-in-lay where the NI was $7.1 \%$ superior to the crosses. The mean percent superiority throughout the period of study was 33.8 with a range of 14.3 to 71.4 . This is similar to the mean superiority of 38\% reported by NWOSU and OMEJE (1985) for the crosses between the LC and GL. The negative percent superiority recorded at the third month-in-lay could be attributed to stress in the crosses. Some of these crosses were removed from their cages and taken to the pens for mating in continuation of the experiment. The stress caused by this transfer and the need to readjust to the floor and the presence of the cock could have led to the drop in their egg production. Within the period of data collection, 196 days, the DR produced 103, crosses 89 and NI 70 eggs. 
The DR egg production was $47 \%$ and $15 \%$ better than the NI and the crosses, respectively, while mean egg production of the crosses was $27 \%$ better than the NI.

Table 4

Least-squares means (g) and standard errors of egg weight of Dahlem Red, Nigeria Indigenous (NI) chicken, their crosses and percent superiority of the crosses over the NI

\begin{tabular}{|c|c|c|c|c|c|c|c|}
\hline \multirow[t]{2}{*}{ Month-in-lay } & \multicolumn{2}{|c|}{ Dahlem Red } & \multicolumn{2}{|c|}{ N. I } & \multicolumn{3}{|c|}{ Crosses } \\
\hline & $\mathrm{N}$ & Mean+S.E & $\mathrm{N}$ & Mean \pm S.E & $\mathrm{N}$ & Mean \pm S.E & $* \% \mathrm{~S}$ \\
\hline 1 & 25 & $51.5 \pm 0.6^{\mathrm{a}}$ & 57 & $31.1 \pm 0.4^{\mathrm{c}}$ & 07 & $35.3 \pm 1.2^{\mathrm{b}}$ & 13.5 \\
\hline 2 & 29 & $52.7 \pm 0.6^{\mathrm{a}}$ & 73 & $33.9 \pm 0.4^{\mathrm{C}}$ & 35 & $39.3 \pm 0.6^{\mathrm{b}}$ & 15.9 \\
\hline 3 & 29 & $53.2 \pm 0.7^{\mathrm{a}}$ & 75 & $35.8 \pm 0.4^{\mathrm{C}}$ & 32 & $40.1 \pm 0.6^{\mathrm{b}}$ & 12.0 \\
\hline 4 & 21 & $54.1 \pm 0.8^{\mathrm{a}}$ & 69 & $35.9 \pm 0.5^{c}$ & 29 & $40.7 \pm 0.7^{\mathrm{b}}$ & 13.4 \\
\hline 5 & 12 & $59.0 \pm 1.0^{\mathrm{a}}$ & 64 & $36.3 \pm 0.4^{\mathrm{c}}$ & 33 & $42.2 \pm 0.6^{\mathrm{b}}$ & 16.3 \\
\hline 6 & 26 & $58.8 \pm 0.7^{\mathrm{a}}$ & 54 & $38.5 \pm 0.5^{c}$ & 30 & $44.3 \pm 0.6^{\mathrm{b}}$ & 15.1 \\
\hline 7 & 23 & $57.8 \pm 0.7^{\mathrm{a}}$ & 58 & $38.6 \pm 0.4^{\mathrm{c}}$ & 28 & $45.8 \pm 0.6^{\mathrm{b}}$ & 18.7 \\
\hline 8 & 24 & $57.4 \pm 0.7^{\mathrm{a}}$ & 56 & $38.5 \pm 0.5^{c}$ & 26 & $46.1 \pm 0.7^{b}$ & 19.7 \\
\hline 9 & 21 & $55.6 \pm 0.9^{\mathrm{a}}$ & 53 & $39.3 \pm 0.5^{c}$ & 26 & $47.0 \pm 0.8^{\mathrm{b}}$ & 19.6 \\
\hline 10 & 21 & $56.9 \pm 0.9^{\mathrm{a}}$ & 35 & $39.7 \pm 0.7^{c}$ & 15 & $48.6 \pm 1.0^{\mathrm{b}}$ & 22.4 \\
\hline $\begin{array}{l}\text { 280-day mean egg } \\
\text { weight }\end{array}$ & 23 & $55.7 \pm 0.8^{\mathrm{a}}$ & 59 & $36.8 \pm 0.5^{c}$ & 26 & $42.9 \pm 0.7^{\mathrm{b}}$ & 16.7 \\
\hline
\end{tabular}

The exotic breed, DR, produced significantly heavier egg than both the NI and their crosses as shown in Table 4. This agrees with the findings of AKINOKUN and DETTMERS (1977) who reported that there was significant breed effect on egg production with the Apollo hen's egg being significantly heavier than those of Ife ecotype hens. The difference in mean egg weight between DR and NI at the fifth monthin-lay was 22.7g. This is higher than what AKINOKUN and DETTMERS (1977) reported for the difference in mean egg weight between the Apollo breed and Ife ecotype. The mean egg weight of $32.3 \mathrm{~g}$ and $48.7 \mathrm{~g}$ recorded for the Ife collection and the Apollo breed, respectively, were also lower than what was recorded for NI and the DR in this study. The reason for the lower egg weight reported for the Apollo breed relative to the DR breed may not be unconnected with the fact that the Apollo is a light egg laying breed when compared to the DR which is a dual purpose breed. Dual purpose and meat breeds are heavier than layer breeds and are expected to produce bigger but fewer numbers of eggs (PAYNE, 1990).

At the fifth month-in-lay, the mean egg weight of the NI was $61.5 \%$ of that of the DR. The mean egg weight of the crosses between the NI and the DR was significantly higher than that of the NI but lower when compared to the DR. This is in agreement with the findings of NWOSU and OMEJE (1985) and NWOSU et al. (1984) who reported that $\mathrm{F}_{1}$ crossbreds were inferior to the exotic in egg weight. This also agrees with the findings of NWOSU and OMEJE (1983) who reported that the weight of eggs from crossbred pullets $(41.1 \pm 0.7 \mathrm{~g})$ showed significant improvement $(\mathrm{P}<0.05)$ over the weight of eggs from the pure local pullets $(32.6 \pm 0.8 \mathrm{~g})$.

Percent superiority of the crosses over the NI ranged between 12.0 and 22.4. From the trend, it could be inferred that percent superiority increased with months-in-lay. This means that the rate of increase in egg weight of the NI eggs decreases with time much more than in the crosses. It is also apparent from the results that percent superiority dropped to 12.0 in the third month-in-lay from 15.9 in the second month-in-lay. This 
could also be attributed to the stress the hens (crosses) may have gone through during the process of transferring them from the cages to the floor for breeding purposes.

Table 5

Least-squares means and standard errors of egg weight (g) of four crosses of chickens between the Nigerian indigenous chicken and Dahlem Red

\begin{tabular}{|c|c|c|c|c|c|c|c|c|}
\hline & & DR $\times$ Fu & & Fu x DR & & DR $\times$ Y & & FuD x DRD \\
\hline Month-in-lay & $\mathrm{N}$ & Mean \pm S.E & $\mathrm{N}$ & Mean \pm S.E & $\mathrm{N}$ & Mean \pm S.E & $\mathrm{N}$ & Mean \pm S.E \\
\hline 2 & 4 & $42.1 \pm 1.3^{\mathrm{a}}$ & 14 & $38.4 \pm 0.7^{b}$ & 13 & $40.1 \pm 0.7^{\mathrm{ab}}$ & 4 & $37.3 \pm 1.3^{b}$ \\
\hline 3 & 4 & $42.6 \pm 1.2^{\mathrm{a}}$ & 13 & $39.1 \pm 0.7^{b}$ & 11 & $40.9 \pm 0.7^{\mathrm{ab}}$ & 4 & $38.9 \pm 1.2^{b}$ \\
\hline 4 & 4 & $42.9 \pm 1.5^{\mathrm{a}}$ & 11 & $40.0 \pm 0.8^{\mathrm{ab}}$ & 11 & $41.5 \pm 0.8^{\mathrm{ab}}$ & 4 & $39.1 \pm 1.3^{b}$ \\
\hline 5 & 4 & $44.9 \pm 2.0^{\mathrm{a}}$ & 13 & $40.9 \pm 1.1^{\mathrm{a}}$ & 13 & $42.9 \pm 1.1^{\mathrm{a}}$ & 3 & $41.5 \pm 2.3^{\mathrm{a}}$ \\
\hline 6 & 4 & $46.3 \pm 1.4^{\mathrm{a}}$ & 11 & $43.0 \pm 0.8^{\mathrm{a}}$ & 11 & $44.6 \pm 0.8^{\mathrm{a}}$ & 4 & $45.3 \pm 1.4^{\mathrm{a}}$ \\
\hline 7 & 3 & $47.5 \pm 1.4^{\mathrm{a}}$ & 11 & $44.8 \pm 0.7^{\mathrm{a}}$ & 11 & $46.4 \pm 0.7^{\mathrm{a}}$ & 3 & $45.3 \pm 1.4^{\mathrm{a}}$ \\
\hline 8 & 4 & $47.8 \pm 1.8^{\mathrm{a}}$ & 11 & $44.9 \pm 1.1^{\mathrm{a}}$ & 10 & $46.4 \pm 1.1^{\mathrm{a}}$ & 3 & $45.7 \pm 1.4^{\mathrm{a}}$ \\
\hline 9 & 3 & $50.3 \pm 2.1^{\mathrm{a}}$ & 6 & $44.6 \pm 1.5^{b}$ & 13 & $47.6 \pm 1.0^{\mathrm{ab}}$ & 4 & $46.0 \pm 1.8^{\mathrm{ab}}$ \\
\hline 10 & 3 & $50.7 \pm 2.1^{\mathrm{a}}$ & 8 & $47.0 \pm 1.3^{\mathrm{a}}$ & 4 & $50.3 \pm 1.8^{\mathrm{a}}$ & & n.a \\
\hline $\begin{array}{l}\text { 252-day mean } \\
\text { egg weight }\end{array}$ & & $46.1 \pm 1.6^{\mathrm{a}}$ & & $42.5 \pm 1.0^{b}$ & & $44.5 \pm 1.0^{\mathrm{a}}$ & & $42.0 \pm 1.5^{b}$ \\
\hline $\begin{array}{l}\text { Age at first egg } \\
\text { (days) }\end{array}$ & 4 & $160.0 \pm 2.6^{\mathrm{a}}$ & 14 & $151.4 \pm 1.4^{\mathrm{b}}$ & 12 & $161.3 \pm 1.5^{\mathrm{a}}$ & 5 & $161.6 \pm 2.3^{\mathrm{a}}$ \\
\hline
\end{tabular}

Weight at first egg for the crosses was not significantly different except in FuD x DRD (Table 5) where it was lower as shown in Table 2. The mean body weight at first egg of 1323g and 1229g recorded for DR x Fu and Fu x DR, respectively, were higher than what OMEJE and NWOSU (1984) reported for the crosses between GL x LC and LC x GL (1186.67g and 1165.09g), respectively. This may be due to the effect of the dual purpose DR. Also age at first egg did not show any significant difference except for Fu x DR that came into lay earlier at 151.4 days. The age at which Fu x DR came into lay is earlier than the $155.4 \pm 1.49$ days reported for LC x GL by OMEJE and NWOSU (1983). Mean age at first egg of 161 days reported for the DR x Fu, DR x Y and FuD x DRD is also lower than 169.7+3.74 reported for GL x LC by OMEJE and NWOSU (1983).

Table 6

Percent hen-day peak egg production and age (weeks) at peak hen-day egg production of crosses between the Nigeria Indigenous chicken and Dahlem Red

\begin{tabular}{lcc}
\hline Location & \%Hen-day peak egg production & $\begin{array}{l}\text { Age at hen-day peak egg production } \\
\text { (weeks) }\end{array}$ \\
\hline DR x Fu & 72.3 & 25 \\
DR x Y & 62.8 & 25 \\
Fu x DR & 62.4 & 25 \\
FuD x DRD & 47.9 & 52 \\
\hline
\end{tabular}

It was observed in Table 6 that all the crosses produced from the crossing of DR and NI (DR x Fu, Fu x DR, DR x Y and FuD x DRD), reached their peak production in their second month-in-lay (25 weeks) except FuD x DRD. DR x Fu reached the highest peak of $72.3 \%$ which is higher than $63.0 \%$ reported by AKINOKUN (1974) for some exotic breeds. FuD x DRD reached its peak production at the 9th month-in-lay with a peak of $47.9 \%$.

The results of the skin test as shown in Figure 2 indicate that the FuD x DRD with a value of $0.45 \mathrm{~mm}$ is expected to be more resistant to diseases. This agrees with what HORST (1988) reported that apart from a reduction in body size and reduced metabolism, genes for dwarfness also confer improved fitness and disease tolerance. 
This is followed by $\mathrm{DR} \times \mathrm{Y}$ and $\mathrm{Fu} \times \mathrm{DR}$ with values of $0.36 \mathrm{~mm}$ and $0.34 \mathrm{~mm}$ respectively. From the same test Y x Y inbred line gave the highest value of $0.50 \mathrm{~mm}$ while the least value of $0.33 \mathrm{~mm}$ was recorded for DR $x$ DR. This shows that the NI had the highest resistance to the induced infection. This result is similar to what SONAIYA et al. (1998) reported for the foundation stock of this study.

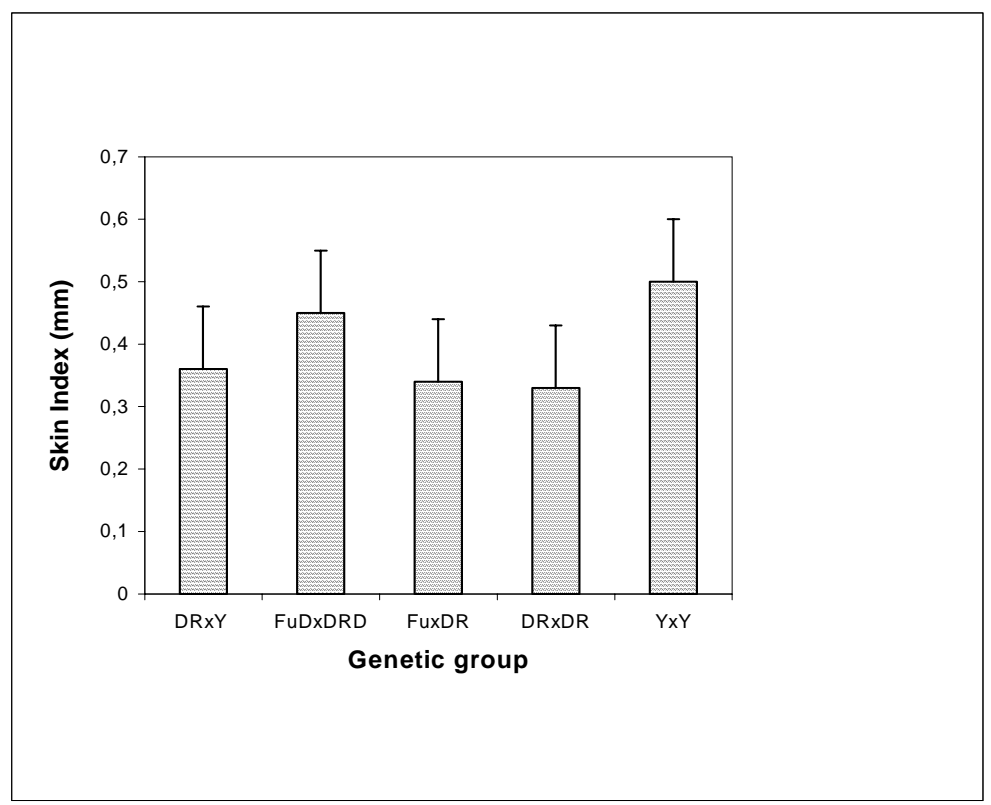

Fig. 2: Skin index of F1 chicken after Phytohaemagglutenin inoculation

\section{References}

AKINOKUN, O.:

The problem of the improvement of poultry production in Nigeria. Niger. Agric. J. 11 (1974), 61-71

AKINOKUN, O.:

An evaluation of exotic and indigenous chickens as genetic materials for development of rural poultry production in Africa. In: SONAIYA, E.B. (Ed). Rural Poultry in Africa: Proceedings of an International Workshop held in Ile-Ife, Nigeria, November 13 - 16, 1989. Ile-Ife. (1990), 56-61

AKINOKUN, O.; DETTMERS, A.:

Performance of the indigenous chickens of Nigeria and the Apollo. 1: Egg weight, rate of egg production and factors affecting them. Nigerian Journal of Animal production, 4 (1977) 1, 67 - 78

ATTEH, J.O.:

Rural Poultry Production in Western Middle Belt Region of Nigeria. In: SONAIYA, E.B. (Ed). Rural Poultry in Africa: Proceedings of an International Workshop held in Ile-Ife, Nigeria, November 13 - 16, HORST, P.: 1989. Ile-Ife. (1990) p 211-217

Native fowl as reservoir for genomes and major genes with direct and indirect effects on production adaptability. Proceedings XVIII World's Poultry Congress, Japan, 4-9 September 1988. 105

NWOSU, C.C.:

Review of indigenous poultry research. In: SONAIYA, E.B. (Ed). Rural Poultry in Africa: Proceedings of an International Workshop held in Ile-Ife, Nigeria, November 13 - 16, 1989. Ile-Ife. (1990) Pp 62-71

NWOSU, C.C.; OBIOHA, F.C.; OMEJE, S.S.I.; GOWEN, F.; BELLONWU, C.T.; ONUORA, G.I.: (1984). Growth performance of Local, Shaver and Starcross chicken under deep litter system of management. Wld. Rev. Anim. Prod. 20 (1984) 2, 17 - 26

NWOSU, C.C.; OMEJE, S.S.I.:

Short-term egg production parameters of the local chicken and its F1 crosses with Gold-Link under two different housing types. E. Afr. Agric. For. J. 51 (1985) 1, 49-53

OLORI, V.E.:

An evaluation of two ecotypes of the Nigerian indigenous chicken. Unpublished M.Sc. thesis, Department of Animal Science, Obafemi Awolowo University, Ile-Ife, Nigeria. 1992 
OMEJE, S.S.I.; NWOSU, C.C.:

Heterosis of early growth in crosses between Gold-Link parent stock and local chickens of Nigeria. 2nd Wld. Cong. Genetics Applied LSK. Prod. Madrid. VIII (SY- 6e - 8) (1982), 847 - 852

OMEJE, S.S.I.; NWOSU, C.C.:

Egg production patterns in local chickens and their crosses in the short term. Nigerian J. Anim. Prod. 10 (1983) 2, 91-96

OMEJE, S.S.I ; NWOSU, C.C.:

Modes of inheritance and interrelationships of age and body weight at first egg and other short-term production parameters in local by exotic crossbred chickens. Proc. XVII Wld. Poultry Congress, Helsinki, Finland. (1984) 791-793

PAYNE, W.J.A.:

An introduction to Animal Husbandry in the Tropics. Fourth edition. ELBS Longman. 1990

SAS:

SAS Users' Guide. Statistics, SAS Inc. USA, 1986 edition

SONAIYA, E.B.; ODUBOTE, I.K.; BAELMAN, R.; DEMEY, F.; WIMMERS, K.; VALLE ZARATE, A.; HORST, P.:

Evaluation of Nigerian local poultry ecotypes for genetic variation, disease resistance and productivity. In: ODUGUWA, O.O., FANIMO, A.O., OSINOWO, O.A. (Eds.). Animal Agriculture in West Africa: The sustainability Question: Proceedings of the silver anniversary Conference of the Nigerian Society for Animal Production (NASP) and the inaugural conference of the West African Society for Animal Production (WASAP). Abeokuta, Nigeria. 21 - 26 March 1998

Received: 2001-04-26

Accepted: 2002-04-12

Corresponding author

ADETAYO S. ADEDOKUN

Department of Animal Science

Faculty of Agriculture

Obafemi Awolowo University

Ile Ife, NIGERIA

E-Mail: sadedok@oauife.edu.ng 